\title{
Humanisme dalam Serat Jangka Jayabaya Perspektif Javanese Wordview
}

\author{
Gusti Garnis Sasmita, Hermanu Joebagio, Sariyatun \\ Universitas Sebelas Maret \\ gustigarnis@gmail.com,sari_fkip_uns@yahoo.co.id, \\ hermanu.joebagio@gmail.com
}

\begin{abstract}
Abstrak
Serat Jangka Jayabaya sebagai salah satu local knowledge masyarakat Jawa memiliki relevansi terhadap sejarah Indonesia pada abad ke- 18 yang strategis untuk digunakan dalam pembelajaran sejarah berbasis nilai. Eksplorasi nilai humanisme dalam Serat Jangka Jayabaya sangat menarik untuk dikaji. Hal tersebut menunjukkan bahwa masyarakat pada abad 18 memiliki pijakan ideal dalam merespon berbagai perubahan sosial. Menggunakan metode penelitian analisis deskriptif dengan pendekatan semiotik denotasi dan konotasi dalam menginterpretasi sastra Jawa, juga pendekatan historis dalam mengaitkan teks terhadap sejarah kepengarangan digunakan untuk mengetahui sejauh mana mentalitas masyarakat Jawa pada masa itu. Nilai humanisme Jangka Jayabaya dieksplanasikan berdasarkan konten, kepengarangan serta kegunaan. Hasilnya menunjukkan bahwa konsep "jangka" sebagai Javanese worldview merupakan petunjuk sekaligus kontrol masyarakat jawa dalam memahami berbagai fenomena sosial. hal tersebut terangkum dalam konsep humanitarian yakni pengetahuan lokal, keadilan, kesederajatan, martabat, serta etika moral. Selain itu, penokohan ahumanis tokoh Jayabaya dalam serat ini di lain sisi justru sengaja ditampilkan pengarang sebagai bentuk kritik humanisme yang mengindikasikan lahirnya humanisme Jawa pada masa itu.
\end{abstract}

Kata kunci: Jangka Jayabaya, Humanisme, Javanese worldview. 


\section{Pendahuluan}

Pentingnya penggunaan local knowledge dalam pembelajaran sejarah sebagai transfer of value merupakan upaya dalam pembentukan karakter humanitarian. Isu belakangan ini ramai diberitakan di media sosial telah banyak menampilkan bentuk - bentuk diskriminasi, intoleransi, serta fanatisme yang berbalut politik identitas. Di sinilah paham kebhinekaan masyarakat Indonesia mulai dipertanyakan kembali. Salah satu tindakan yang dapat menanggulangi dampak-dampak isu sosial khususnya terhadap generasi muda adalah dengan pembelajaran sejarah sebagai character building. Dalam hal ini diperlukan sebuah sumber sejarah yang memiliki nilai-nilai humanis dan dapat direfleksikan dalam permasalahan kekinian. Salah satu di antaranya adalah dengan menggunakan manuskrip Jawa yang kaya akan kearifan lokal. Dipilihnya Serat Jangka Jayabaya sebagai manuskrip jawa dalam model pembelajaran bukan tanpa sebab, terlebih jika menguak konten menarik yang terkandung di dalamnya. Dalam mengupas intisari dari Serat Jangka Jayabaya, peneliti akan menggunakan dua sudut pandang, yakni analisis berdasarkan konten penokohan dan isi narasi

Penggunaan teori semiotik denotasi dan konotasi dalam analisis teks sastra akan mengungkap makna di balik simbol atau pertanda. Denotasi sebagai tingkat pertandaan yang menjelaskan hubungan penanda dan petanda pada realitas, menghasilkan makna eksplisit, langsung, dan pasti. Sedangkan konotasi sebagai tingkat pertandaan yang menjelaskan hubungan penanda dan petanda yang di dalamnya beroperasi makna yang 
tidak eksplisit, tidak langsung, dan tidak pasti. Konotasi sudah menguasai masyarakat akan menjadi mitos. ${ }^{1}$ Makna konotasi meliputi aspek makna yang berkaitan erat dengan perasaan dan emosi serta nilai-nilai kebudayaan dan ideologi. ${ }^{2}$ Sebagai contoh, makna jangka secara bahasa diartikan sebagai ramalan, ramalan merupakan hal yang syirik dan tidak dapat dipercaya. maka, jangka dikenal sebagai mitos bagi sebagian masyarakat Terkait dengan local knowledge masyarakat terhadap konsep "jangka" atau ramalan yang merujuk pada pemahaman ngelmu titen, yang secara lanjut dilakukan guna ketercapaian bawana tentrem dalam ihwal space culture sekaligus spiritual culture falsafah memayu hayuning bawana. ${ }^{3}$ Memayu hayuning bawana sebagai Javanese worldview Worldview diartikan sebagai cara pandang masyarakat jawa dalam melihat dan mengerti segala sesuatu di alam dan kehidupanya.

Pemikiran tersebut muncul karena setiap manusia mengetahui bahwa realitas dapat dipahami dan diartikan secara berbeda oleh setiap masyarakat berdasarkan cara pandangnya. Maka guna memperindah alamnya "bayuning-bawana" masyarakat jawa harus mampu menempatkan diri sesuai dengan nilai etika dan moral dalam setiap tindakannya, sehingga keseimbangan bawana terwujud melalui kecerdasan, baik intelektual, emosional maupun spiritual. Nilai humanis dalam Serat Jangka Jayabaya merupakan petunjuk yang dapat digunakan sebagaik refleksi historis guna

\footnotetext{
${ }^{1}$ Yusita Kusumarini, Teori Semiotik (Surabaya: Universitas Kristen Petra, 2006), 31.

${ }^{2}$ Yasraf Amir Piliang, Hipersemiotika Tafsir Cultural Studie Atas Matinya Makna (Yogyakarta: Jalasutra, 2003), 54.

${ }^{3}$ Endraswara, Memayu Hayuning Bawana (Jakarta: Narasi, 2013), 16-17.
} 
melihat berbagai permasalahan sosial yang marak terjadi dalam masyarakat Indonesia dewasa ini. Hal tersebut dapat digunakan dalam pembelajaran sejarah, sebagaimana pada masa kesultanan Mataram, Serat Jangka Jayabaya digunakan sebagai pedoman kehidupan bermasayarakat sekaligus kontrol sosial.

Penelitian ini menggunakan pendekatan kualitatif yang menurut paradigma postpositivisme digunakan untuk meneliti pada kondisi obyek yang alamiah, dimana peneliti berperan sebagai instrumen kunci, dan hasil penelitian kualitatif lebih menekankan makna dari pada generalisasi ${ }^{4}$. Pengumpulan data menggunakan metode wawancara dengan beberapa ahli tafsir sastra Jawa beserta analisis dokumen. Data primer dalam penelitian ini adalah Serat Jangka Jayabaya koleksi museum Radyapustaka, dan data sekunder berupa salinan Serat Jangka Jayabaya dalam aksara Jawa koleksi perpustakaan Universitas Sebelas Maret dan buku terjemahan Serat Jangka Jayabaya karya Suyami dengan judul Kajian Budi Pekerti dalam Serat Jangka Jayabaya maupun sumber penunjang lainnya. Adapun wawancara dilakukan kepada berbagai ahli seperti tafsir sastra jawa R. Adi Deswijaya, S.S., M.Hum selaku salah satu tenaga pendidik sastra jawa UNIVET, Totok Yasmiran selaku petugas alih naskah sekaligus penerjemah manuskrip Jawa Museum Radya Pustaka, dr . R. Wisnu Kusumawardana selaku ahli tafsir filsafat serta berbagai pihak dalam kegiatan diskusi bersama. Wujud data kualitatif kemudian dianalisis

\footnotetext{
${ }^{4}$ Sugiyono, Metode Penelitian kuantitatif, kualitatif dan R\&D (Bandung: Alfabeta, 2011), 27.
}

32 | Gusti Garnis Sasmita, Hermanu Joebagio, Sariatun - Memahami Serat Jangka Jayabaya 
dengan pendekatan CDA (Critical Discourse Analysis) dimana analisis wacana kritis dilakukan terhadap wacana yang berkembang dan dikembangkan oleh pihak-pihak yang berkepentingan, memiliki kekuasaan, dengan memproduksi wacana dominan untuk menguasai ruang publik agar pihak-pihak lain juga ikut terdominasi dan terkuasai. Sebagaimana sastra Jawa yang memiliki relasi dialektikal antar wacana dan elemen dalam kehidupan sosial pengarang/penyadur yang penuh dengan aneka karakter dengan proses-proses perjuangan politik

Adapun upaya penarikan nilai-nilai humanis dalam Serat Jangka Jayabaya menggunakan teori semiotik teks tentang simbolisme atau pertanda dalam suatu teks. Analisis teks merupakan analisis sebuah kelompok atau kombinasi berupa kumpulan tanda yang membentuk teks. Pada dasarnya teks mengandung representasi sikap, ideologi, atau mitos tertentu. Dalam hal ini teks dalam Serat Jangka Jayabaya tampaknya tidak hanya mengandung konotasi tetapi juga denotasi. Konotasi tanda berkaitan dengan kode nilai, makna sosial, dan berbagai perasaan, sikap, atau emosi. Tiap teks adalah kombinasi sintagmatik tanda-tanda yang melalui kode sosial tertentu menghasilkan konotasi tertentu. Konotasi yang berbeda bergantung pada posisi sosial pembaca dan faktor lain yang mempengaruhi cara berpikir dan menafsirkan teks. Konotasi yang diterima luas secara sosial akan menjadi denotasi atau makna teks yang dianggap benar. Denotasi merepresentasikan mitos budaya, kepercayaan, dan sikap yang dianggap benar. 


\section{Javanese Worldview: Konsep Humanisme Dalam Serat Jangka}

\section{Jayabaya}

Dalam memahami Javanese worldview yang tercermin dalam serat ini, pelurusan makna jangka yang lebih luas bukan hanya perihal ramalan yang dipercayai dalam mitologi jawa. Jangka sebagai petunjuk dalam kehidupan bermasyarakat dicerminkan dari berbagai nilai humanisme dalam manuskrip tersebut. Hal ini dikarenakan sebuah petunjuk dalam kehidupan bermasyarakat hendaklah senantiasa berpegang tegung pada konsep kemanusiaan. Walaupun jika kita lihat bersama persoalan kemanusiaan abad 18 dengan masa kini memang dua hal yang berbeda. Akan tetapi hal ini dapat digunakan sebagai refleksi historis masyarakat di mana nilai humanisme Serat Jangka Jayabaya masih sangat ideal diterapkan dimasa kini.

Penelitian lain berjudul "Serat Jangka Jayabaya: Relasi Sastra, Sejarah dan Nasionalisme" menunjukkan bahwa terdapat konten menarik dalam manuskrip tersebut sehingga memiliki pengaruh besar terutama pada awal mula lahirnya benih nasionalisme. Hal itu dilandasi kepercayaan setempat atau kejawen yang merujuk pada ideologi pengabsahan pergerakan resistensi melawan penjajahan pada masa kolonialisme abad ke-195. Jika dalam penelitian tersebut memfokuskan diri terhadap konsep Ratu Adil sebagai mesias atau pembebas terhadap berbagai kekacauan zaman yang merujuk pada diskursus resistensi terhadap kolonialisme, dalam penelitian

\footnotetext{
5 Sasmita, G, "Serat Jangka Jayabaya: Relasi Sastra, Sejarah dan Nasionalisme", Historica Volume 6 Nomor 2 (2018), 391-402.
} 
ini membahas local knowledge yang terdapat dalam Serat Jangka Jayabaya sehingga mampu mempengaruhi (sekaligus berakar dalam) mentalitas masyarakat Jawa. Apa sebenarnya gagasan humanisme yang telah tumbuh pada masa tersebut dan bagaimana refleksi yang dapat dilakukan pada masa kini.

Sebelum dilakukan analisis terkait nilai-nilai humanisme yang terdapat dalam Serat Jangka Jayabaya, terlebih dahulu dijabarkan pengertian dari humanisme itu sendiri. Humanisme merupakan suatu pandangan atau paham yang menjunjung tinggi harkat dan martabat manusia yang mana setiap manusia memiliki kedudukan, keistimewaan serta keunikan masingmasing. Sehingga manusia sebagai pusat dari alam semesta bisa menjaga setiap perbuatan guna tercapainya keselarasan hidup. Seseorang yang telah mampu berpedoman pada nilai-nilai humanis dalam setiap pemikiran dan perbuatannya disebut sebagai humanitarian. Maka, seseorang yang telah atau sedang mempelajari sejarah adalah dalam upaya mewujudkan pribadi humanitarian. Hal ini didasarkan pada sumsi bahwa dalam setiap penjelasan sejarah atau eksplanasi sejarah diharapkan memberikan nilainilai positif dan kebermanfaatan berdasarkan esensi peristiwa masalalu dalam refleksi kekinian. Eksplanasi Serat Jangka Jayabaya merupakan upaya merevitalisasi nilai-nilai local genius masyarakat Jawa.

Sebagai acuan nilai humanitarian dalam membedah Serat Jangka Jayabaya, Figur Abdurrahman Wahid dipilih sebagai humanitarian ideal. Hal ini mengacu pada pendapat Greg Barton setelah menelusuri pemikiran dan tulisan Abdurrahman Wahid menemukan sebuah tema paling 
dominan dalam pemikiran Gus Dur, yaitu humanitarianisme. ${ }^{6}$ Adapun prinsip humanitarian tersebut adalah local knowledge (pengetahuan lokal), equity (keadilan) dan equality (kesederajatan atau persamaan). Seseorang yang humanis pada dasarnya memiliki kemampuan intelektual serta menjunjung tinggi nilai keadilan dan persamaan/kesederajatan. Prinsip tersebut digunakan sebagai refleksi serat Jangka Jayabaya karena dianggap memiliki karakteristik humanitarian yang ideal yakni tercermin dari berbagai pemikiran dan gagasan Abdurrahman Wahid tentang humanisme di tengah kehidupan berbangsa dan bernegara. Deskribsi nilai humanis dalam Serat Jangka Jayabaya bisa dipaparkan sebagai berikut;

\section{Pengetahuan lokal (Local knowledge)}

"Punika cariyosipun Prabu Jayabaya kala katamuan pandhita saking Rum anama Molana Ngali Samsujen. Prabu Jayabaya langkung kurmat dening katamuan pandhita linuwih, misuwur, saget amemaca, uninga saderenging winarah. Prabu Jayabaya lajeng purubita ing sasuraosing jangka ingkeang gaib-gaib, wadosing cipta sasmita..."

Diceritakan suatu ketika Raja Jayabaya bertemu dengan pendeta (ahli agama) dari negeri Rum yang bernama Maulana Ali Samsuzen. Prabu Jayabaya menghormati beliau sebagai pendeta yang memiliki pengetahuan (kemampuan) lebih, terkenal, serta dapat membaca, mengerti sebelum terjadi. Raja Jayabaya kemudian diberi pengetahuan terkait jangka yang gaib-gaib dan tanda yang bersifat rahasia ${ }^{7}$. Dalam penggalan ini ditampilkan bagaimana jangka merupakan suatu pengetahuan empirik yang

\footnotetext{
${ }^{6}$ Greg Barton, Liberalisme Dasar-Dasar Pemikiran Abdurrabman Wabid (Yogyakarta: LkiS, 1997), 166-167.

7 Suyami, Kajian Budi Pekerti dalam Serat Jayabaya (Yogyakarta: Balai Pelestarian Nilai Budaya Yogyakarta, 2015), 125.
} 
dilestarikan secara turun temurun guna memahami atau membaca berbagai peristiwa untuk dapat memproyeksikan masa depan agar lebih baik daripada masa kini. Pengetahuan yang semacam ini, pada konteks kontemporer sangat berkaitan dengan pembelajaran sejarah. Karena memlalui sejarah seseorang akan mampu mempelajari berbagai peristiwa masa lalu agar tidak kembali terjadi kejadian dengan pola yang sama pada masa kini dan masa depan.

"Sasampunipun rampung panganggiting jangka Prabu Jayabaya ingkang kababaraken dados lalampahaning jaman satunggal-satunggal, kestokaken dening Molana Ngali Samsujen..."

Sesudah selesai menggubah jangka yang dijelaskan menjadi pembabakan zaman satu per satu, Raja Jayabaya lalu mepertunjukkan hasilnya kepada pendeta Maulana Ali Samsuzen. Dalam bait tersebut tampak adanya akulturasi terhadap pengetahuan awal dengan keyakinan Jayabaya dalam memahami berbagai fenomena sosial yang ada. Hal tersebut merupakan salah satu bentuk enkulturasi yakni proses internalisasi nilai norma kebudayaan yang dialami seorang individu dimana pola kebudayaan yang diterima berdasarkan pembawa kebudayaan sebelumnya dianggap ideal dan diakulturasi terhadap konsep diri.

"Prabu anom adhiku, lajeng matur menggah tegesipun sesegah wau, dumungpun ing kraton satunggal-satunggal..." Raja Anom adikku, adapun arti sesungguhnya dari sesuguhan tadi ada kaitannya dengan kerajaan satu per satu. Bahkan seorang rajapun memiliki penjelasan di balik segala tindakan yang telah diperbuatnya. Hal tersebut merupakan cerminan bahwa 
transparasi memang diperlukan dalam setiap tindakan yang ditujukan kepada khalayak umum atau kebaikan bersama.

Seseorang dikatakan sebagai humanitarian ketika ia memiliki kompetensi intelektual sesuai dengan bidang yang ia kuasai. Sebagai contoh, seorang raja harus memiliki kecerdasan intelektual, emosional dan spiritual, seorang mahasiswa pendidikan sejarah memiliki kemampuan dalam melakukan eksplanasi sejarah dengan ketrampilan dalam berbagai tahapan metodologi sejarah, baik dalam heuristik, kritik, interpretasi dan historiografi. Pengetahuan lokal atau local knowledge sebagaimana dijelaskan oleh Nygren, merupakan sebuah istilah yang problematik yang justru dianggap tidak ilmiah jika dibandingkan dengan pengetahuan Barat. Titik temu antara pengetahuan lokal yang tidak ilmiah dan yang ilmiah tersebut berdasar pada rasionalitas Barat dimana keduanya berada pada bagaimana cara memahami dunia mereka sendiri. Pengetahuan lokal dapat ditelusuri dalam berbagai bentuk baik pragmatis maupun supranatural. Akan tetapi, justru pola demikian merupakan hal yang rasional bagi masyarakat Jawa dalam memahami setiap kejadian. Pertanda sebagaimana diakumulasikan secara empirik kemudian di-sebarluaskan secara turun temurun dari generasi ke generasi berikutnya.

Penokohan Jayabaya dalam Serat Jangka Jayabaya yang merupakan symbol dari local knowledge dapat dilihat bagaimana ia menggunakan kompetensi yang dimiliki guna memecahkan permasalahan yang akan dihadapi rakyatnya di kemudian hari yang disimbolkan dengan penghayatan tapa semedi. Hal ini jika direfleksikan pada masa kini dapat 
diartikan sebagai pembelajaran dalam konteks lifelong learning, dimana setiap orang mampu mengkonstruksi pengetahuan yang ia dapat dan mengkombinasikan dengan konstruksi pengetahuan di dalam dirinya sendiri.

Raja yang dianggap sebagai sosok pemimpin yang senantiasa diagungkan oleh rakyatnya pastilah seseorang yang memiliki kompetensi dalam berbagai hal baik secara intelektual maupun spiritual seperti halnya Raja Jayabaya yang dianggap sebagai pengejawantahan Dewa Wisnu di muka bumi. Jayabaya memiliki tanggung jawab terhadap kesejahteraan rakyatnya menggunakan pengetahuan lokal yang ia dapat dari gurunya, dikembangkan dan disebarluaskan untuk kemaslahatan umat manusia. Hal tersebut tercermin dalam Serat Jangka Jayabaya yang menceritakannya tokoh Jayabaya yang datang menemui pendeta dari Rum, Maulana Ali Samsuzen untuk ngangsu kaweruh atau mencari ilmu dan diperlihatkanlah jangka atau ramalan tentang zaman-zaman sesuai dengan Kitab Musarar.

Jayabaya sebagai seorang raja tidak lantas congkak dan merasa puas terhadap pengetahuan yang dimilikinya. Seseorang yang belajar, sesuai teori konstruktivisme, mampu mengkonstruksi pengetahuannya secara mandiri. Disini Jayabaya melakukan tapa semedi setelah mendapatkan kaweruh dari Maulana Ali Samsuzen. Kemudian Ia mampu mengartikan arti dari simbolisme 7 suguhan yang pernah diberikan oleh Ajar Subrata sebagaimana ia menggubah jangka yang dijelaskan menjadi pembabakan zaman satu persatu dan mempertunjukkan hasilnya kepada pendeta 
Maulana Ali Samsuzen. Kemudian dijabarkanlah arti dari sesuguh tersebut kepada adiknya Raja Anom.

Ramalan atau jangka ialah pengejawantahan pengalaman empirik masalalu atau dalam istilah jawa dikenal sebagai ngelmu titen. Sehingga, disini Jayabaya secara empirik memaknai dalam setiap kejadian, baik yang telah atau sedang terjadi, agar bermakna untuk sesama sebagaimana ungkapan "bistory make man wise" dan Historie vitae magistra: yakni pembelajaran sejarah sebagai guru terbaik dalam mengantarkan umat manusia menjadi bijaksana dan bermartabat.

\section{Keadilan (Equity)}

Keadilan merupakan sebuah simbol dari terlaksananya kesejahteraan. Maka seorang yang humanis adalah seseorang menjunjung tinggi nilai keadilan. Didalam Serat Jangka Jayabaya khususnya pada pembabakan zaman kalabendu ditampilkan berbagai kekacauan yang terjadi dalam suatu masyarakat. Kekacauan tersebut menggambarkan bahwa rakyat semakin sengsara akibat raja yang hanya memikirkan harta sehingga pajak rakyat semakin naik, bahkan rakyat yang tak mampu membayar dengan barang yang ditentukan memberikan pajak dengan berbagai wujud. Jika dilihat dari latar belakang kepengarangan nampaknya terkait keadilan dalam pajak merujuk pada pengenalan sistem pajak oleh pemerintah kolonial Belanda terutama terkait pajak tanah. Dalam hal ini unsur dari materialisme dan egosentrisme penguasa ditampilkan dengan sangat jelas oleh pengarang.

"Ing sajroning jaman kalabendu ana jamaning ratu hartati, tegese sarupaning manungsa kang kaestbi mung harta...wadale wong cilik warna-warna, ana metu 
mas salaka, beras pari sapanunggalane,.... ing ngantara mangsa sangsaya mundhak mundhak pajeging wong cilik..."

Didalam zaman kalabendhu ada zamannya Ratu Hartati, (berasal dari kata harta + ti yang berarti kekayaan atau ekonomi) sejenis manusia yang hanya memikirkan harta pajak rakyat kecil yang bermacam-macam, berupa mas salaka, beras, padi dan lain sebagainya. Disuatu masa semakin naiklah pajak rakyat kecil. ${ }^{8}$ Berdasarkan penggalan tersebut, terlihat bagaimana ratu yang hanya memikirkan kekayaan pribadi sehingga kesejahteraan rakyat tidak diperhatikan, berbagai macam pajak mengindikasikan bahwa rakyat sudah tidak mampu membayar pajak berupa emas atau uang, sehingga apapun yang dimilikinya digunakan untuk membayar pajak.

"Karana sangsaya mundak-mundak muksibating nagara, kongsi retu adiling ratu, amarga wong agunge pada jabil, wong cilik podo jawal..."

Karena semakin banyaknya musibah yang menimpa negara, tidak ada ratu yang adil karena pembesarnya berhati jahat dan orang kecilpun nakal. Kekacauan yang terjadi dalam penggambaran zaman kalabendhu secara jelas ditegaskan oleh pengarang dalam gambaran ketiadaan ratu yang adil. Pemimpin sebagai panutan yang mengemban tanggung jawab dalam setiap kehuidupan rakyatnya tidak lagi memikirkan kesejahteraan rakyat kecil, tetapi justru sibuk dalam memperkaya diri.

"Apngaling wong asalin-salin... kerep ana prang, sujana-sarjana kontit, durjana dursila saya andadra,... ing wektu ik.u wus parek wekasaning jaman kalabendu, ing kana harjaning tanah jawa wus ilang mamalaning bumi, amarga sinapih tekaning ratu ginaib, wijiling utama...... jumeneng ratu pinandhita adil paramarta, lumub maring arta, kasebut nama sultan Herucakra..."

\footnotetext{
${ }^{8}$ Suyami, Kajian Budi Pekerti, 133.
} 
Sifat manusia berubah-ubah, sering terjadi perang, orang-orang berpengetahuan dan berpendidikan semakin tersingkir itu tanda sudah dekat akhir zaman kalabendhu digantikan zaman kejayaan tanah jawa, sudah hilang musibahnya bumi karena dihentikan oleh raja gaib, lahir dari kebaikan, beliau menjadi raja yang adil dan sabar, tidak suka pada harta, dikenal dengan nama sultan Herucakra. ${ }^{9}$

Kutipan serat tersebut menggambarkan bagaimana seseorang akan kehilangan jatidirinya hingga menampilkan berbagai perilaku ahumanis karena kondisi sosial yang tidak lagi benar, Sementara pembesar yang dianggap sebagai panutan justru bertindak tidak benar. Hal ini ditunjukkan berdasarkan ungkapan apngaling wong asalin-salin, perilaku orang berubahubah atau plin-plan yang berarti tidak memiliki pendirian tetap, kongsi retu adiling ratu, adanya keadaan yang buruk/kekacauan tanpa hadirnya ratu adil, dan berbagai ungkapan lainnya yang mengindikasikan bahwa tanpa keadilan berbagai kekacauan akan terjadi dalam suatu masyarakat.

Konsep ratu adil ditampilkan sebagai harapan terhadap pembebasan berbagai kekacauan, sebagai sosok ratu gaib yang membebaskan musibah bumi. Secara harfiah hal itu merujuk pada pemaknaan bahasa Jawa terhadap penokohan Herucakra terdiri dari dua kata yakni heru yang berarti hera-heru atau huru hara atau perlambang terhadap permasalahan atau kekacauan. Sedangkan cakra berarti roda. Jika dikaitkan dengan senjata, cakra merupakan senjata milik Dewa Krisna yang mampu menghentikan jagad raya termasuk matahari (dalam kisah Bharatayuda). Maka, Herucakra

\footnotetext{
${ }^{9}$ Suyami, Kajian Budi Pekerti, 134.
} 
merupakan perlambang seseorang yang mampu menumpas berbagai kekacauan yang dihadapi pada zaman kalabendhu. Lalu sesungguhnya yang menarik disini adalah siapakan sultan Herucakra. Secara filosofis, setiap manusia memiliki sosok Herucakra (juru selamat) didalam dirinya masing-masing, karena keadilan diciptakan dan bukan ditemukan. Manusia diberi akal budi pekerti oleh Tuhan untuk dapat menentukan nasibnya. Setiap pijakan dalam tindakan manusia senantiasa bertitik tumpu pada nilai keadilan, adil terhadap diri sendiri dan orang lain.

\section{Kesederajatan (equality)}

Persamaan dan kesederajatan dalam nilai humanis Barat diartikan dengan penyamarataan atas hak dan kewajiban setiap orang. Namun, kesederajatan dalam konteks budaya Timur bukan sekedar pengakuan akan kesamaan derajat melainkan bagaimana seseorang mampu bertindak sesuai dengan derajat diri dan posisinya (mampu menempatkan diri dalam setiap situasi dan kondisi). Ia mampu mengenali siapa dirinya dan mampu bertindak sesuai dengan peran yang ia miliki secara bertanggung jawab. Sebagai contoh, jika hal ini direfleksikan pada masa kini, bagaimana seorang mahasiswa harus mampu bertindak sesuai dengan etika yang ia miliki sebagai bagian dari proses belajar. Seorang penguasa harus mampu menempatkan diri layaknya Herucakra. Konsep ini juga berkaitan dengan kemampuan intelektual.

"Punika cariyosipun Prabu Jayabaya kala katamuan pandhita saking Rum anama Molana Ngali Samsujen. Prabu Jayabaya langkung kurmat dening katamuan pandhita linuwih, misuwur, saget amemaca, uninga saderenging winarah." 
Diceritakan suatu ketika Raja Jayabaya bertemu dengan pendeta (ahli agama) dari negeri Rum yang bernama Maulana Ali Samsuzen. Prabu Jayabaya menghormati beliau sebagai pendeta yang memiliki pengetahuan (kemampuan) lebih, terkenal, serta dapat membaca, mengerti sebelum terjadi. ${ }^{10}$

"duh wrubanira kulup kulup ingsun, iki panjanmaning wisnu murti, kabubuhan agawe harjaning bumi-bumi...." Ketahuilah bahwa sesungguhnya aku adalah pengejawantahan Dewa Wisnu untuk menjaga kedamaian (kesejahteraan) bumi.

Seorang Jayabaya di dalam Serat Jangka Jayabaya menyatakan diri sebagai pengejawantahan atau titisan Dewa Wisnu mengisyaratkan bahwa ia adalah seorang yang beragama Hindu tetapi tetap menjunjung tinggi nilai kesederajatan tatkala ia menerima pengetahuan dengan seorang pendeta dari Rum, yang beragama Islam Maulana Ali Samsuzen. Di sini jayabaya mengakui adanya kesederajatan walaupun dalam bingkai perbedaan.

Untuk memahami manuskrip Jawa, tidak dapat diilepaskan dari konsep martabat (dignity) dan nilai (value). Nilai humanisme akan menjadikan seseorang bermartabat. Nilai moral dan etika adalah dasar terbentuknya martabat tersebut. Setiap serat memiliki tuntunan atau wejangan kepada generasi muda, sembari mengingatkan nilai budaya luhur yang perlu dilaksanakan dan dilestarikan.

10 Suyami, Kajian Budi Pekerti, 135. 
Martabat akan menciptakan sebuah keadaan yang harmonis dalam kehidupan. Sebaliknya, hilangnya martabat pada diri sseorang akan menyebabkan kekacauan. Dalam hal ini, martabat akan tercapai ketika seseorang mampu menempatkan diri di dalam perannya di masyarakat. Proses pemartabatan diri bisa dicapai melalui pendidikan yang mengarah pada transfer of knowledge and value.

Nilai dan moralitas merupakan pedoman kehidupan bermasyarakat. Nilai-nilai ini senantiasa mengalami pergeseran sepanjang zaman. Revitalisasi nilai-nilai local genius diperlukan dalam pembelajaran. Serat Jangka Jayabaya sebagai salah satu sumber sejarah menggambarkan bagaimana kekacauan dalam setiap zaman memiliki penyelesaian, yang bukan hadir dari orang asing melainkan dari jati diri yang dihayati bersama sesuai dengan nilai budaya Jawa.

Gambaran di atas merupakan kajian penokohan Jayabaya sebagai figur humanitarian dengan jangka yang ia sampaikan. Pengarang juga memberikan hal menarik yang justru bertentangan dengan kaidah humanitarian: dapat dilihat pada bait dimana Jayabaya menumpas Ajar Subrata yang merupakan murid Maulana Ali Samsuzen. Menumpas dalam sastra memang tidak dapat diartikan sebagai membunuh, akan tetapi secara luas adalah mematikan pengaruh terhadap suatu kondisi. Dalam hal ini, Ajar Subrata dapat dikatakan sebagai lawan politik Jayabaya, yang dapat mengancam jangka yang telah ia buat.

Tindakan tersebut merupakan perilaku ahumanis, dimana seharusnya seorang pemimpin tidak menggunakan dalih kesejahteraan dalam pembenaran perilaku politik yang ia lakukan. Jika hal ini, ditarik pada zaman Ranggawarsita 
sang penyadur naskah, latar belakang sosio kultural merupakan alasan kuat mengapa naskah tersebut ditedhak kembali. Bahkan pada masa tersebut popularitas Jangka Jayabaya semakin meningkat tatkala konsep Ratu Adil yang di-adaptasi dalam Serat Jangka Jayabaya, dikembangkan menjadi kritik sosial dalam serat Kalathida yang sangat terkenal dengan istilah zaman edan. Adaptasi tersebut merupakan suatu bentuk enkulturasi dimana ia menganggap harus ada keberanian dalam kritik sosial daripada pendahulunya yang banyak menyadur naskah tersebut.

Kepedulian terhadap ketertindasan masyrarakat pribumi baik rakyat jelata, bangsawan maupun kaum terpelajar merupakan dasar bagaimana paham himanisme mulai lahir pada masa itu. Kolonialisme sebagai gambaran kekacauan dimana seseorang diperlakukan secara tidak manusiawi justru menumbuhkan kesadaran pentingnya menghargai harkat dan martabat manusia, terlepas dari kelas sosial yang ia sandang. Terkucilkannya Ranggawarsita dari lingkungan keraton, sehingga ia menjalin relasi akademis Mangkunegaran IV terutama dalam berbagai penulisan sastra Jawa, secara tidak langsung merupakan bentuk ketidakharmonisan dengan kasunanan. Melalui gubahan Serat Jangka Jayabaya, ia menampilkan kembali sebuah kritik kepada penguasa atas tindakan yang kurang pantas. Ia memberi gambaran bahwa dalam melegitimasi kekuasaan seorang pemimpin, dengan dalih kesejahteraan rakyat, bisa menghalalkan segala cara dengan menyingkirkan pihak-pihak yang dianggap mengganggu. 


\section{Local Genius Masyarakat dalam Konsep Jangka}

Pembelajaran sejarah secara kontekstual tidak terlepas dari nilai. Di dalam setiap sumber sejarah, baik tersirat maupun tersurat, selalu terdapat nilai yang ingin disampaikan. Serat Jangka Jayabaya merupakan sember sejarah berupa dokumen-manuskrip-serat peninggalan kerajaan Mataram Islam sekitar abad ke-18 yang sumber kitab musarar. Hal ini merujuk pada kitab Asrar karangan Sunan Giri ke 3 yang ditulis pada tahun 1618 M. Kitab Jangka Jayabaya pertama dan yang dianggap asli adalah karya Pangeran Wijil I dari Kadilangu yang mendapat sebutan Pangeran Kadilangu II, yang dikarang pada tahun 1741-1743 $\mathrm{M}^{11}$.

Dari sisi konten, Serat Jangka Jayabaya merupakan sebuah sinkretisme Islam-kejawen. Hal ini tampak pada akulturasi budaya dalam bagian pembuka, ketika diceritakan Sang Prabu Jayabaya bertemu dengan gurunya Maulana Ali Samsudin. Dari hal tersebut, diketahui bahwa agama Islam memiliki nilai toleransi yang besar antar sesama, Yang mengajarkan nilainilai kebaikan dan kemanusiaan. Disisi lain, agama Islam juga dapat dimaknai memiliki kedudukan yang lebih tinggi dari pada Hindu, terlihat dari bagaimana seorang Raja Jayabaya, sebagai pengejawantahan Dewa Wisnu, justru berguru kepada seorang Muslim. Selain itu, bagaimana pembabakan zaman yang menampilkan tujuh zaman juga mengindikasikan adanya pencampuran unsur Islam dengan kejawen yang mana dalam agama islam sangat sering menggunakan angka tujuh seperti dalam ungkapan langit sap 7.

\footnotetext{
11 Soewarno, Ramalan Joyoboyo versi Sabdopalon (Kediri: Cagar Budaya, 2004), 65.
} 
Serat Jangka Jayabaya berakar pada mentalitas orang Jawa secara luas. Hal tersebut dipahami sebagaimana local genius masyarakat terhadap konsep jangka atau ramalan yang merujuk pada pemahaman ngelmu titen, yang secara lanjut dilakukan guna ketercapaian bawana tentrem dalam ihwal space culture sekaligus spiritual culture falsafah memayn baynning bawana ${ }^{12}$. Kepercayaan masyarakat Jawa atau yang sering disebut dengan kejawen memiliki ketertarikan yang besar terhadap berbagai hal-hal seperti jangka, ramalan dan klenik. Hal ini berhubungan dengan local knowledge masyarakat yang senantiasa memahami berbagai peristiwa secara kosmologis. Beberapa jangka dalam karya sastra lama sangat menarik untuk dikaj, ditinjau dari popularitasnya yang tak pernah surut dari perbincangan.

Seiring dengan arus modernisasi, masyarakat mulai kritis terhadap kesahihan sebuah jangka. Jangka secara konotasi seringkali diartikan sebagai ramalan, sementara ramalan secara denotasi dimaknai sebagai hal berbau syirik atau musyrik karena mempercayai kehendak lain selain Tuhan. Akan tetapi, secara interpretasi teks, Jangka dalam Serat Jangka Jayabaya merujuk pada pengertian petunjuk atau pertandasebagaimana jangka menunjukkan gambaran zaman-zaman seperti halnya kitab suci Alquran.

Petunjuk yang demikian seyogyanya merupakan pengetahuan terhadap akumulasi pengalaman empiris yang terangkum menjadi satu. Sedangkan pertanda dapat diartikan sebagai keterangan dari petunjuk tersebut. Maka, Serat Jangka Jayabaya lebih tepat jika diartikan sebagai

\footnotetext{
12 Endraswara, Memayu, 16-17.
} 
petunjuk yang diperoleh melalui metode keilmuan dan spiritual kapujanggan. Namun, persepsi yang justru berkembang dalam masyarakat menganggap Jangka Jayabaya sebagai mitos atau takhayul terkait pemaknaan "ramalan" yang cenderung mengarah pada makna denotasi kesesatan. Untuk memahami lebih lanjut isi dari petunjuk yang sengaja direpresentasikan oleh pengarang dalam karya ini bisa dengan cara mendalami berbagai simbolisme dalam manuskrip tersebut.

Dalam karya sastra jawa, simbolisme memegang peranan atas terhadap ketercapaian penyampaian nilai kepada khalayak umum. Simbolang digunakan sebagai perantara pemahaman terhadap obyek yang merupakan perlambang, berupa suatu benda, keadaan, atau hal lain yang memiliki arti. Manusia adalah mahluk budaya, dan budaya manusia penuh dengan simbol-simbol. Dapat dikatakan bahwa budaya manusia penuh diwarnai oleh simbolisme, tata pemikiran yang mengikuti pola-pola mendasarkan diri pada simbol-simbol. ${ }^{13}$

Simbol yang digunakan oleh satu masyarakat dengan masyarakat lainnya berbeda satu sama lain. Kata pujangga berasal dari bahasa sanskerta bhujangga yang artinya ular, dianggap sebagai lambang kebijaksanaan yang istimewa, Sebaliknya, simbol ular bagi kebudayaan Barat dianggap sebagai simbol setan atau keburukan ${ }^{14}$. Maka untuk memahami sebuah simbol, kita perlu menempatkan diri pada sudut pandang tempat dan waktu di mana simbol tersebut digunakan. Secara

\footnotetext{
${ }^{13}$ Herusatoto, Simbolisme Jawa (Yogyakarta: Ombak, 2008), 46.

14 Ibid., 98-99.
} 
harfiah Jayabaya menurut Adi Kusumawardhani dan Totok Yasmiran, merujuk pada kata jaya yang berarti berjaya atau menang. Sedangkan baya berarti bebayan atau bahaya atau sebuah simbol masalah. Jadi, Serat Jangka Jayabaya merupakan sebuah gambaran bagaimana tokoh utama menang dalam mengatasi permasalahan melalui berbagai petunjuk-petunjuk zaman. Alasan terkait pemilihan Jayabaya sebagai tokoh utama oleh pengarang dalam manuskrip ini merujuk pada keterhubungan nilai-nilai dengan tokoh tersebut. Perspektif pengarang mengisyaratkan bahwa masa pemerintahan Jayabaya merupakan hal ideal bagi masyarakat untuk mencapai kesejahteraan. Hal ini senada dengan kondisi yang diharapkan oleh pengarang pada masa lalu, renaisans Jawa. Oleh karena itu, salah satu nilai sentral yang dapat dicuplik dari serat ini adalah nilai kedamaian atau peace building.

Nilai merupakan sesuatu yang penting dari kebudayaan. Pergeseran nilai dalam masyarakat berkembang senantiasa mempengaruhi perubahan folkways dan mores. Hal ini dipengaruhi oleh faktor intern maupun ekstern dalam suatu masyarakat. Secara eksternal, nilai dalam masyarakat Jawa mengalami pergeseran antara sebelum dan sesudah penjajahan Belanda. Filsafat Jawa yang senada dengan eksistensialime humanis mengalami pergeseran ke arah materialisme. Pergeseran nilai yang dipegang oleh sekelompok orang tertentu dalam masyarakat merupakan sebuah anomali tatkala terjadi ketidaksesuaian dengan nilai yang dianut sebelumnya. Hal ini dapat dikategorikan sebagai penyimpangan sosial. Secara sederhana kita dapat menyatakan bahwa seseorang menyimpang apabila menurut 
anggapan sebagian besar masyarakat perilaku atau tindakan tersebut di luar kebiasaan, adat-istiadat, aturan, nilai atau norma sosial yang berlaku) ${ }^{15}$

Untuk menjelaskan isi zaman kalabendu pada Serat Jayabaya, kita perlu meminjam teori penyimpangan sosial, yakni bagaimana kekacauan terjadi pada zaman tersebut, apa penyebabnya dan bagaimana penyelesaiannya. Terjadinya pergeseran perilaku masyarakat sebagaimana ditunjukkan oleh Serat Jangka Jayabaya pada zaman kalabendu, yang mana salah satunya ditunjukkan oleh uangkapan apngaling wong asalin-salin, merupakan ungkapan atas kondisi seseorang yang berubah-ubah, plin-plan dan kehilangan jati dirinya. Keterkaitan penyimpangan harus dihubungkan dengan konteks waktu dan tempat terjadinya penyimpangan. Artinya nilai dan norma yang berlaku di dalam satu kelompok sosial bisa saja tidak berlaku pada kelompok sosial lainnya. ${ }^{16}$

Nilai moral dan budi pekerti yang ditampilkan dalam Serat Jangka Jayabaya merupakan pencerminan nilai humanis yang diungkapkan pengarang melalui pencitraan tokoh Jayabaya dalam jangka tujuh zaman. Menurut yasmiran serat jayabaya merupakan gubahan Raden Ngabei Ranggawarsita. ${ }^{17}$ Dalam kepenulisan, seorang pujangga memiliki konsepsi yang sama dengan budaya literasi masa kini. Hal ini tampak dalam kajian intertekstualitas serat yang memiliki hubungan dengan serat lainnya. Seorang pujangga dalam karyanya seringkali memuat kutipan karya lain

\footnotetext{
15 E. M. Setiadi, Kolip, Pengantar Sosiologi Pemahaman Fakta dan Gejala Sosial: Teori, Aplikasi dan Pemecabannya (Jakarta: Kencana Prenada Group, 2018), 187.

16 Ibid., 188.

17 Wawancara dengan Yasmiran, 17/02/2018
} 
yang berkenaan dengan konsep pedoman yang di pegang teguh. Sarat Jangka Jayabaya merupakan karya gubahan atau tedhakan yang senantiasa dilestarikan karena dianggap memiliki nilai luhur dan relevan pada zaman Ranggawarsita.

Konsep ratu adil atau heru cakra menjadi esensial ketika simbol kesejahteraan diharapkan menjadi resolusi bagi ketimpangan sosial yang terjadi di masyarakat. Pola pikir berdasarkan ramalan merupakan perwujudan dari mentalitas masyarakat Jawa tradisional. Namun, kesalahan persepsi yang berkembang dalam masyarakat menganggap Sang Maharaja Sri Aji Jayabaya sebagai seorang pencipta dari jangka tersebut. Mungkin itu terjadi karena secara tidak langsung Serat Jangka Jayabaya menyebutkan bahwa ia mengkonstruksi pengetahuan yang bersifat mengembangkan ramalan jaman sesuai Kitab Musarar yang ditunjukkan oleh pendeta Maulana Ali Samsuzen.

Pada dasarnya muatan dalam serat Jayabaya memiliki titik temu, yakni konten yang sama mengenai harapan terhadap kondisi yang seharusnya. Hal ini merupakan prinsip hidup masyarakat Jawa yang sangat memperhatikan tatanan norma masyarakatdan budi pekerti luhur. Gubahan Serat Jayabaya karya Ranggawarsita memiliki daya tarik tersendiri jika dihubungkan dengan sosio kultural kepengarangan. Bagaimana sosok Ranggawarsita kemudian mampu menghidupkan kembali serat Jayabaya yang diadopsinya sehingga menghasilkan serat Kalatidha, yang dalam serat Jayabaya berarti zaman kalabendu. Dari sinilah kemudian konsep ratu adil hingga sampai saat ini melekat pada pandangan masyarakat Jawa. 
Konsep kesejahteraan akan dapat terwujud tatkala ada sosok juru selamat. Jika ditarik dalam konteks pembelajaran sejarah, juru selamat merupakan pengetahuan itu sendiri atau siswa yang mampu memahami dan mengkonstruksi pengetahuannya agar mampu mencari dan mengusahakan kesejahteraan dan keselamatan atas dirinya sendiri serta lingkungan di sekitarnya. Di sinilah mengapa perlu dilakukan kajian intertekstual terhadap serat Jayabaya dalam narasi sejarah. Teori intertekstualitas dalam sastra didefinisikan oleh Kristeva sebagai bagunan teks melalui mozaik kutipan-kutipan atau sebagai penyerapan dan transformasi dari teks lain. ${ }^{18}$

\section{KESIMPULAN}

Konsep Jangka dalam Serat Jangka Jayabaya merujuk pada pengertian petunjuk atau pertanda sebagaimana jangka menunjukkan gambaran zamanzaman, Misalnya dalam kitab suci Alquran. Petunjuk seyogyanya merupakan pengetahuan akumulatif dari pengalaman empiris yang terangkum menjadi satu. Sedangkan pertanda dapat diartikan sebagai keterangan dari petunjuk tersebut. Maka, Serat Jangka Jayabaya lebih tepat jika diartikan sebagai petunjuk yang diperoleh melalui metode keilmuan dan spiritual kapujanggan memiliki relevansi jika diterapkan pada masa kini.

Nilai humanisme sebagai esensi manuskrip tersebut tercermin dalam prinsip humanitarian penokohan Jayabaya dengan: (1) local knowledge

\footnotetext{
${ }^{18}$ M. B. Leckrone, Teori Sastra dan Julia Kristeva (Denpasar: Bali Media Adikharsa, 2005), 76.
} 
sebagaimana simbol raja yang memiliki kemampuan tinggi tetapi tetap berguru kepada orang lain yang memiliki pengetahuan lebih, (2) equity ditunjukkan oleh berbagai kekacauan dalam pembabakan zaman kalabendu akibat tidak adanya ratu adil diselesaikan melalui datangnya seorang misianis sebagai Raja yang adil hingga rakyatnya kembali makmur, dan (3) equality yang ditunjukkan oleh penerimaan Raja Jayabaya Hindu berguru kepada orang Muslim, Maulana Ali Samsuzen. Seseorang dikatakan bermartabat jika ia mampu menempatkan diri dalam segala situasi dan kondisi dan senantiasa berpegang teguh kepada etika dan moral agar senantiasa menjadi juru selamat untuk dirinya sendiri dan orang sekitar.

Seorang humanitarian, harus menyelaraskan pikiran, perkataan dan perbuatan. Seorang pemimpin sebagai panutan rakyatnya tidak dibenarkan melakukan perilaku ahumanis guna kepentingan humanis karena hal tersebut tidak mencerminkan martabat kemanusiaan. Iaharus mampu bertindak sesuai dengan tempatnya. Adapun sisi ahumanis yang ditampilkan pengarang dalam manuskrip ini menunjukkan bagaimana protes humanisme ditujukan kepada pemimpin masyarakat. Hal ini mengindikasikan bahwa pada abad ke 18 dan19 Masehi telah lahir paham humanisme Jawa sebagai dampak dari kolonialisme bangsa Barat. 


\section{REFERENSI}

Barton, Greg. Liberalisme Dasar-Dasar Pemikiran Abdurrabman Wabid. Yogyakarta: LkiS, 1997.

Endraswara, S. Memayu Hayuning Bawana. Jakarta: Narasi, 2013.

Herusatoto, B. Simbolisme Jawa. Yogyakarta: Ombak, 2008.

Kusumarini, Yusita. Teori Semiotik. Surabaya: Universitas Kristen Petra, 2006.

Leckrone, M. B. Teori Sastra dan Julia Kristeva. Denpasar: Bali Media Adikharsa, 2005.

Narwoko, D., \& Suyanto, B. Sosiologi Teks Pengantar Terapan. Jakarta: Prenada, 2014.

Nasution. Metode Research: Penelitian Ilmiah. Jakarta: Bumi Aksara, 2003.

Piliang, Yasraf Amir. Hipersemiotika Tafsir Cultural Studie Atas Matinya Makna. Yogyakarta: Jalasutra, 2003.

Purwanto, B. Gagalnya Historiografi Indonesiasentris. Yogyakarta: Ombak, 2006.

Purwasito, A. Imageri India. Surakarta: UNS Press, 2017.

Ratna, N. K. Postkolonialisme Indonesia Relevansi Sastra. Yogyakarta: Pustaka Pelajar, 2008.

Ratna, N. K. Postkolonialisme Indonesia Relevansi Sastra. Yogyakarta: Pustaka Pelajar, 2008.

Ray, S. Gayatri Cakravorty Spivak-Sang Liyan. Denpasar: Bali Media Adikharsa, 2009. 
Sasmita, G. G. Serat Jangka Jaybaya: Relasi Sastra, Sejarah dan Nasionalisme. Historia, Vol. 6, No. 2, 2018.

Schulte, H. Persepektif Baru Penulisan Sejarah Indonesia. Jakarta: Yayasan Pustaka Obor Indonesia, 2013.

Setiadi, E. M., \& Kolip, U. Pengantar Sosiologi Pemahaman Fakta dan Gejala Sosial: Teori, Aplikasi dan Pemecahannya. Jakarta: Kencana Prenada Group, 2010.

Soewarno, H. Ramalan Joyoboyo versi Sabdopalon. Kediri, 2004.

Spivak, G. C. Acritique of Postkolonial Reason Toward a History of the Vanishing Present. London: Harvard University Press, 1999.

Sugiyono. Metode Penelitian Kuantitatif, Kualitatif dan R\&D. Bandung: Alfabeta, 2011.

Suyami. Kajian Budi Pekerti dalam Serat Jayabaya. Yogyakarta: Balai Pelestarian Nilai Budaya (BPNB) Yogyakarta, 2015.

Yasmiran, T. (2018, Februari 17). Kepengarangan Serat Jangka Jayabaya. (G. G. Sasmita, Interviewer) 